\title{
EXAMINING LANGUAGE LEARNING STRATEGIES USED BY KURDISH MONOLINGUAL (KURDISH) AND BILINGUAL (KURDISH-ARABIC) SPEAKERS AS EFL LEARNERS
}

\author{
Hozan Gorgeen Othman
}

Dept. of English Language, Faculty of Humanities, University of Zakho, Kurdistan Region, Iraq.

Received: 02. 2017 / Accepted: 04. 2017 / Published: 09. 2017

https://doi.org/10.26436/2017.5.3.445

\begin{abstract}
:
This study investigates the difference between monolingual (Kurdish) and bilingual (Kurdish-Arabic) speakers as EFL (English as a Foreign Language) learners with regard to the use of Language Learning Strategies (LLS). It aims to identify the differences found between the two samples in terms of using the (LLS). A total number of 100 EFL students at Zakho University as Bilinguals and Duhok University as Monolinguals of English Departments of both universities participated in the study. All the participants were third and fourth year undergraduate students from both universities. They were asked to answer a questionnaire on Rebecca Oxford's Strategy Inventory for Language Learning known as SILL. The strategies followed in this paper are the direct ones (memory, cognitive, compensation) and the indirect ones (meta-cognitive, affective, and social) which are highlighted in Oxford (1990). These strategies are chosen for this paper because they are considered to be the most agreed upon ones by many writers in the area of English as a Foreign Language (EFL). The valid and reliable statistical 'independent t-test' of SPSS is used to analyze the data. It is hypothesized that the results will show significant differences between the two groups (monolinguals and bilinguals) in their strategies in favour of bilinguals. The results of the research reveal that all strategies are clearly and soundly used by both groups, and surprisingly there is no significant difference between bilinguals and monolinguals with regard to the use of the six strategies. It was also found that there is no significant difference between third and fourth year levels concerning the use of the mentioned strategies, as well as there are two identical favourite lists of LLS for both groups. KEYWORDS: Language Learning Strategies (LLS), Monolingual, Bilingual, EFL/ESL Learners, SILL Questionnaire.
\end{abstract}

\section{INTRODUCTION}

There has recently been a notable shift within the sphere of language teaching and learning with greater importance given to learning and learners rather than to teaching and teachers. Along with this new move, the matters of how learners deal with new information, what types of strategies they use for understanding, learning or remembering new language chunks have been the top priorities of researchers involved in the sphere of foreign language learning. The claim that states monolinguals and bilinguals have the ability to learn an additional language in different ways has received an extensive interest in the studies of second and/or foreign language acquisition and learning. Besides, reflecting personally on how a learner learns a language is viewed as a secret to a scholastic mastery of the learning of second or foreign language. In other words, learners must be aware of the fact that they have inner abilities and strength by which they can gain as much language as possible. Griggs (1991: 85) states that everybody has a learning style, and if that style fits in his/her learning strategy, it will "result in improved attitudes toward learning, an increase in productivity, academic achievement, and creativity". Thus, researchers have examined a range of features of learners, and learning strategies have welcomed a prominent attention in this regard. Many researchers highlight that successful learners utilize different techniques and strategies efficiently so as to overcome the difficulties they face during the learning or acquisition process of a language. Research also shows that these strategies allow learners to obtain more confidence and responsibility in their development of learning another language. According to Oxford (1990: 1) language learning strategies (LLS henceforth) are significant as "they are tools for active, self-directed involvement, which is essential for developing communicative competence", and they lead to "improved proficiency and greater self-confidence".

Now that the current paper has adopted Rebecca Oxford's classification of the LLS, a detailed account needs to be given to each of the six categories Oxford reached at. As stated earlier, she classifies LLS into direct and indirect categories. The former ones "require mental processing of the language" (Oxford, 1990). While the latter ones offer indirect support through using various strategies such as evaluating, arranging, focusing, and lowering anxiety etc. (Ibid). The direct ones are made up of memory, cognitive and compensation strategies. By memory strategies she means "creating mental linkages", "applying images and sounds", "reviewing well", and "employing action". (p. 17). They generally refer to the mental processes by which learners can store new information in their memories and retrieve them whenever it requires them to. The cognitive strategies include "practicing", "receiving and sending messages", "analyzing and reasoning", and "creating structure for input and output". These involve conscious and intentional ways of treating new chunks of foreign or second language. As for the compensation strategies, which consist of "guessing intelligently" and "overcoming limitations in speaking and writing", the learners will have abilities to use spoken and written skills of language in spite of facing knowledge gaps. On the other hand, the indirect strategies, which are indirect supportive strategies for learners, consist of metacognitive, affective, and social strategies. Metacognitive encompasses aspects like "overviewing and linking new expressions with already known material", "seeking practice opportunities", "paying attention to new language chunks", "organizing", "self-evaluating", "self-monitoring", and "purposeful reading/writing/listening/speaking". While, affective strategies entail "lowering learner's anxiety" by laughing and taking a deep breath while using the foreign language, as well as "encouraging yourself" through taking 
risks wisely and rewarding one's self. It also includes having "a diary or checklist" for new words as well as "discussing one's feelings" with other people. All these affective aspects help learners get motivation for language learning and manage their emotions and attitudes towards learning a foreign or second language. Finally, social strategies simplify the difficulties of language learning through conversations and interactions with native speakers or even non-native EFL speakers. They include "asking questions" for correction or clarifications, "cooperating with proficient users", and focusing on "developing cultural understanding" as well as "becoming aware of others' thoughts and feelings".

Skehan (1989) believes that LLS are the most significant factors building individual differences when it comes to language learning. Ellis \& Sinclair (1989) suggest that "the aim of learning strategies is fundamentally one of self-examination and insight into and control over one's learning". This study intended to examine the potential distinctions between bilingual and monolingual learners concerning the application of (LLS) whilst learning English language. The hypotheses and questions of the current study are the following:

1. Do Kurdish monolingual and bilingual EFL speakers use the six LLS highlighted in Oxford's work or not?

Hypothesis1: The Kurdish monolingual and bilingual EFL speakers clearly use the LLS stated in Oxford work.

2. Is there any significant difference between Kurdish bilingual and monolingual English language learners with regard to LLS?

Hypothesis2: There exists a significant difference between Kurdish bilingual and monolingual EFL learners in reference to using LLS in favor of bilinguals.

3. Is there any difference in using these strategies between the two groups' levels (third and fourth year levels of the sample)? Hypothesis3: There is a significant difference in using LLS between the two groups of the sample (third and fourth year) levels.

4. Is there any significant difference between both groups of learners with reference to utilizing various favorite categories of LLS i.e. Compensatory, Memory, Cognitive, Affective, Metacognitive and Social?

Hypothesis 4: There exists a significant difference between both groups with regard to employing different categories of LLS.

The importance of this paper lies in the fact that no identical studies, to the best of the researcher's knowledge, have been conducted on Kurdish EFL/ESL learners especially at the undergraduate level. This, doubtlessly, will contribute something to the ESL/EFL literature on the part of Kurdish language learners. It might as well provide Kurdish EFL teachers at university level with some options of teaching and learning to choose from when setting or designing their course books and curriculums for EFL classes. The paper consists of five parts. The first one is an introduction to the topic. The second tackles the literature associated with LLS. Section three highlights the methodology adopted for the paper. Part four is devoted to the results of the paper and their discussions. Finally, section five provides a conclusion to the study.

\section{LITERATURE REVIEW}

The assumption that some social and cognitive variables influence language learning has been around for quite a long time now. The use of LLS is probably the most notable one in this regard. A range of lists and classifications of LLS have been tackled and developed by many famous researchers, academics, and writers such as O'Malley, Chamot, and Oxford who are considered to be the best representatives of language learning matter. Brown (2007); Zare (2010); Baker and Boonkit (2004); Oxford (2003) state that research on LLS began in the 1970s. Ellis \& Sinclair (1989) and Weaver \& Cohen (1997) point out that "learning how to learn" is currently considered as a necessary and a critical element of language learning process from which strategy instructions and learners' trainings became known. White (2008: 9) defines LLS as "the operations or processes which are consciously selected and employed by the learner to learn the target language or facilitate a language task". Meanwhile Griffiths (2013: 36) illustrates that LLS are "activities consciously chosen by learners for the purpose of regulating their own language learning". Oxford (1990) states that "LLS, are steps taken by the learners in order to improve language training and develop language competence" and she categorized the LLS, into direct and indirect strategies including behaviors, memory information, grammar rules, vocabulary learning, thought and mental processes. She goes on highlighting that "learning strategies are specific actions taken to ensure that learning is made simpler, faster, more enjoyable, more self-directed, more effective, which can even be transferable to new situations".

The idea is more illuminated by Weaver and Cohen (1997) who stress that LLS are the conscious behaviors and thoughts employed by ESL or EFL students with plain objective of increasing their acquaintance of a target language. In the majority of the studies done on LLS, recognizing what to do to be a good learner of EFL or ESL has been the central concern. In 1975 Rubin investigated the most successful LLS in her study when she highlighted what the good language learners can teach others. She states that good LLS can be a program or syllabus to be used for the low leveled students and learners. Then, Wenden (1986) showed that studying the good language learners' strategies would be a constructive activity which can raise the learners' awareness to a number of successful learning strategies. Thus, these strategies were later on described extensively by a number of experts in TESOL field such as O'Malley et al (1985), Ellis (1994), Stern (1992), Oxford (1990) to mention but few. Their strategies ever since have helped creating instructional and pedagogical framework and scaffold for learners. It is worth to mention that there is almost a general consensus on LLS categorizations among the experts of this sphere. That is why it could be right to claim that no fundamental changes can be found in most of their works. In other words, the classifications O'Maley, Rubin, Chamot, Oxford gave in their works can be quite comparable. For instance, O'Maley et al. (1985) classify LLS into Socioaffective, Cognitive and Metacognitive strategies. Rubin (1987), as well, divides them into three categories but through direct and indirect classifications. His three categories include learning, communication, and social strategies. However, Oxford (1990), who is considered to be the one who came up with the most comprehensive classes of LLS, separates them into six categories under direct and indirect taxonomies. Two years later i.e. (in 1992) Stern published his work on the same subject dividing the LLS into five subdivisions which are: management and planning strategies, interpersonal strategies, cognitive strategies, communicative - experiential strategies, and affective strategies.

It is worth to mention that a number of researches and studies in English speaking countries such as USA or UK or even nonEnglish speaking countries have been conducted on the current topic, however; one can rarely find decent studies conducted 
on the use of language learning strategies in a country like Kurdistan of Iraq where bilingual and multilingual speakers exist. Additionally, it can be claimed that the majority of the studies related to this area have been conducted on monolinguals. And because Kurdistan is a place where one can find many bilinguals (Kurdish \& Arabic) EFL and ESL learners in, the need of studies aiming at discovering the relationship between LLS and bilinguals is thought to be of great importance especially for academics and researchers who are involved in learning and teaching. Therefore, this study tries to examine the relationship between monolinguals and bilinguals in reference to LLS use in handling English language as a foreign language. What distinguishes this study from others is the fact that it draws a comparison between the strategy use of Kurdish-Arabic bilinguals and Kurdish monolinguals.

\section{3. .METHODOLOGY}

The participants consist of 100 bilingual and monolingual ELT undergraduate students of Zakho and Duhok Universities (both of whom studying at English language departments). They comprise 100 male and female participants from two levels; 50 third year students and 50 fourth year students. The SILL questionnaire of Rebecca Oxford consisting of 50 statements based on the five-point Likert-scale system was used for this study. The questionnaire was anonymously completed in the hope that the participants' responses could directly address the research aims and questions. Data analyses were performed by SPSS program (version 22) using the 'T-test' type of statistical program to answer the research questions. To rule out any potential obscurity and to save time, the researcher, being present with each participant while filling in the questionnaire, provided an oral translation of SILL questions as some participants struggled understanding a number of questions written in the questionnaire. The SILL questionnaire is made up of 6 parts each of which focusing on a particular strategy. The first part i.e. (A) is on 'Memory Strategy' which includes 9 questions. The second part (B) tackles 'Cognitive Strategy' which is of 14 questions. The third part (C) is specified for 'Compensation Strategy' that has 6 questions. Part (D) contains 9 questions on 'Meta-cognitive Strategy'. Part (E) which comprises 6 questions is revolved around 'Affective Strategy'. And finally part (F) which deals with 'Social Strategy' incudes 6 questions as well. All together they become 50 questions on the six different strategies of language learning. See the questionnaire which is attached in appendix 1 .

\section{RESULTS AND DISCUSSIONS}

The current section provides the results of the study followed by their discussions. The first question set in this study was to investigate whether the Kurdish monolingual and bilingual EFL speakers utilize the LLS or not. And to reach to this goal, the researcher used the $T$ value and $T$ table (critical value) as well as the standard deviation degrees for the sample. Then, the 'T-test' was applied on it. The results of the study indicate that all of the six strategies of language learning discussed by Rebecca Oxford are used by both groups to a great extent as shown in table 1 .

Table 1. The 'T-test' result of using LLS by monolingual and bilingual Kurdish EFL speakers

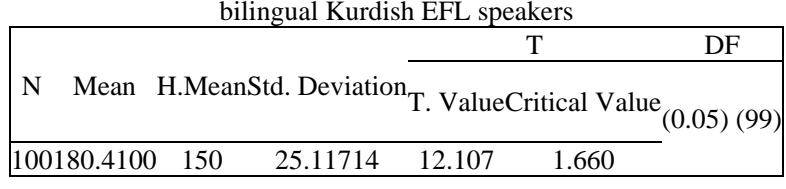

Table 1 demonstrates that the obtained $t$ value with 99 degree of freedom at 0.05 level of significance is 12.107 . This means that there is a significant difference among the six categories of SILL questionnaire used by bilinguals and monolinguals. Since this value is higher than the critical value (T.Table) for $t$ $(12.107>1.660)$ it means that the answer to the first question of the study is positive. If it was below (1.660), it would have indicated that the mentioned strategies are not frequently used by the sample participants. So, this means that the researcher's first hypothesis concerning the use of the mentioned strategies for Kurdish monolingual and bilingual EFL speakers is right, and the correct answer to the first question is 'Yes'. This result matches with the results of many previous conducted studies (Abdulrazak et al. 2012; Qasimnejad and Hemmati 2014; Gerami and Baighlou 2011; Hong-Nam and Leavell 2006) focusing on the same topic but taking different languages into their accounts. In other words, the results of the mentioned studies also state that the strategies in question are frequently and sometimes far too often used by the participants. However, it contradicts the results of Al-Otaibi (2004) and Al-Haisoni (2012) in which the Saudi language learners of English used the six strategies at a moderate level.

The results of the second question, which were very surprising, showed that there is no significant difference between both groups with respect to using the LLS as shown in table 2.

Table 2. The 'T-test results of the two independent samples for the language variable

\begin{tabular}{|c|c|c|c|c|c|c|}
\hline \multirow[b]{2}{*}{ Language } & \multirow[b]{2}{*}{$\mathrm{N}$} & \multirow[b]{2}{*}{ Mean } & \multicolumn{4}{|c|}{$\mathrm{T}$} \\
\hline & & & $\begin{array}{c}\text { Std. } \\
\text { Deviation }\end{array}$ & T.Value & $\begin{array}{c}\text { Critical } \\
\text { Value }\end{array}$ & DF \\
\hline Kurdish & 50 & 177.8400 & 26.86577 & 1.023 & 2.00 & $\begin{array}{c}(0.05) \\
(98)\end{array}$ \\
\hline $\begin{array}{l}\text { Kurdish- } \\
\text { Arabic }\end{array}$ & 50 & 182.9800 & 23.22427 & & & \\
\hline
\end{tabular}

To investigate which sample (i.e. bilinguals or monolinguals) use LLS more, the researcher gained the mean and standard deviation of the sample for the language variable and applied the 'T-test' on the two independent samples. As table 2 indicates, the $t$ value is 1.023 which is lower than the critical value of $t(1.023<2.00)$. This implies that there is no significant statistical difference between the mean of the two groups of the sample. This surprising result is inconsistent with the study of Qasimnejad \& Hemmati (2014), in which there is a clear significant difference between Persian bilinguals (speaking Persian and Turkish) and monolinguals (speaking Persian) in favour of bilinguals. It is also different from the results of McLaughlin \& Nayak (1989) and Nayak et al. (1990). The results of McLauglin and Nayak also indicate that bilinguals use and have more access to LLS and exhibit higher skills and abilities than monolinguals. There might be different interpretations for this unexpected result. A possible reason is probably the fact that the number of participants was not so big, as compared to other studies, to get a more representative result for both groups. If the researcher had the opportunity to take 300 or 400 hundred participants sample, probably there would have been different results than the current ones. Neils (2006) states that for the confidence level of research to be high (i.e. around $95 \%$ ) your sample size should include 500 participants in your study. The lack of facilities and time limit made it difficult for the researcher to gain a larger number of participants for this study. Another reason could also be that both groups in both universities are following a comparable English language curriculum, especially the two universities share a number of professors and similar modules as they are two neighboring universities and have quite parallel approaches and methods of teaching and learning. Had the researcher chosen two very different and far away, in location, 
universities from each other with different teachers and different approaches and methods of teaching and learning, the results, again, could have been rather different than the current ones. The final potential reason, in researcher's viewpoint, for having this unexpected result is that the monolingual speakers (those only speak Kurdish) have a partial access to Arabic language because of the language contact that exists between the Kurds and Arabs who are living side by side in Kurdistan and Iraq. In other words, the monolingual group of the sample of this study is not a sample that has no ideas about Arabic language at all. On the contrary, some of them understand Arabic to a certain extent, and some other ones have the ability to read Arabic texts and passages based on the environments they live in (neighboring each other). Richard and Shmidt (2002) define monolingual as "a person who has an active knowledge of only one language, though perhaps a passive knowledge of others". This means that monolinguals sometimes have a partial access to other languages and they understand a limited range of it/them as it is the case with a number of the monolingual participants of the current study. In fact, De Angelis (2007) goes even further and claims that "humans can be argued to be multilingual by default, with the option of being monolingual or bilingual depending on a number of factors" (p.2). This means that even if one is monolingual, s/he has a partial access to other languages. So, based on what is mentioned, the second hypothesis of this study is not in accordance with the results of the study which clearly means the researcher's second hypothesis is wrong.

Concerning the third question of the study which was about the possibility of having any differences between the levels of both samples, the results show that there is, again, no significant difference between the levels of both groups with regard to using LLS. In other words, the two samples, having two levels (third and fourth year undergraduate learners), use all strategies quite identically and frequently. Table 3 demonstrates the results reached at for the third question of the study.

Table 3. The 'T-test' results of both samples for the variable of level

\begin{tabular}{|c|c|c|c|c|c|c|}
\hline \multirow[b]{2}{*}{ Level } & \multirow[b]{2}{*}{$\mathrm{N}$} & \multirow[b]{2}{*}{ Mean } & \multirow{2}{*}{$\begin{array}{c}\text { Std. } \\
\text { Deviation }\end{array}$} & \multicolumn{2}{|c|}{ T-test } & \multirow[b]{2}{*}{ DF } \\
\hline & & & & T. Value & $\begin{array}{c}\text { Critical } \\
\text { Value }\end{array}$ & \\
\hline Three & 50 & 178.6400 & 28.42517 & 0.703 & 2.00 & (0.05) \\
\hline Four & 50 & 182.1800 & 21.45302 & & & \\
\hline
\end{tabular}

To examine which level (i.e. third or fourth year students) use LLS more, the researcher, once more, obtained the mean and standard deviation of the sample for the level variable and applied the 'T-test' on the two different (monolingual and bilingual) groups. As table 3 states, the $t$ value is 0.703 which is, in this case as well, lower than the critical value of $t(0.703$ $<2.00)$. This, for the second time in this paper, implies that there is no significant difference between the means of the two levels of the sample. If the $t$ value was higher than the critical value of $t$, the use of LLS for one level would have been higher than the other. Although the research shows that (see Bremner, 1997; Wharton, 2000) more experienced language learners utilize more strategies than the less experienced ones, this study does not show any important difference between the two levels. A possible reason behind this could be that the two levels are very close to each other with reference to their proficiency and competence in English language. One year difference in level might not be enough to draw a proper comparison between two levels of language learners. If the comparison was between undergraduate and postgraduate students having a big gap of proficiency level between them, the study might have given us different results than the ones the researcher gained. So, the third hypothesis of this study is not correct and contrary to expectations too, and this is perhaps not very surprising because as Scrivener (2011: 87) highlights "the majority of classes (of students) are made up of mixed-levels which is a noticeable problem that many teachers complain about".

Finally, the last question of the study was about whether both groups have different preferences regarding the six strategies of LLS. The results, as shown in table 4, reveal that unpredictably both groups have very similar favorite lists of LLS strategies with the highest percentage of preference for part B of the questionnaire (cognitive strategies) followed by part D (metacognitive strategies). Likewise, both groups chose part E (affective strategies) and part C (compensation strategies) to be their least favorite strategies to use for learning the SL which is in this case English language.

Table 4. The sequence of the six strategies for both groups according to their mean

\begin{tabular}{|lccc|}
\hline Strategies & $\begin{array}{l}\text { Monolinguals } \\
\text { Mean }\end{array}$ & $\begin{array}{l}\text { Bilinguals } \\
\text { Mean }\end{array}$ & $\begin{array}{l}\text { General } \\
\text { Mean } \\
\text { of Both } \\
\text { Groups }\end{array}$ \\
\hline 1. B (Cognitive) & 50.34 & 51.44 & 50.89 \\
2. D (Metacognitive) & 34.44 & 35.52 & 34.98 \\
3. A (Memory) & 29.66 & 30.42 & 30.04 \\
4. F (Social) & 22.06 & 22.76 & 22.41 \\
5. E (Affective) & 20.70 & 21.70 & 21.20 \\
6. C (Compensation) & 20.64 & 21.14 & 20.89 \\
\hline
\end{tabular}

Notice that cognitive strategies (i.e. part B) has the highest mean for both groups with 50.34 for monolinguals and 51.44 for bilinguals. It is followed by metacognitive strategies (i.e. part D) which recorded 34.44 for monolinguals and 35.52 for bilinguals respectively. Having cognitive and metacognitive strategies appearing at the top of the list is not surprising as Oxford (1990b) highlights that both strategies are considered to be the most widespread strategies among language learners for them to be successful. It is also in line with the results of Chang (2011) and Liu (2004) who confirm that both cognitive and metacognitive come first when listing the six strategies in order. However, as stated in the above table there is no difference in the sequence of any of the six strategies for both groups which is also considered to be an unanticipated result as the researcher, in light of some previous studies e.g. (AlHaisoni, 2012; Qasimnejad and Hemmati, 2014), expected to have some differences in the sequence of the six strategies when comparing monolingual and bilingual LLS to each other.

\section{CONCLUSIONS AND IMPLICATIONS}

This paper investigated the differences between Kurdish monolingual (mastering only Kurdish) and bilingual (mastering Kurdish and Arabic) EFL speakers with regard to using language learning strategies. Undergraduate bilingual and monolingual Kurdish learners stated that they apply all the six categories of LLS stated in Oxford's work to a great extent when learning English language. A result of the study surprisingly indicates that there is no significant difference between both groups of the study when using the LLS while learning English. This finding clearly contradicts other important studies conducted on the same topic but with different languages than Kurdish and Arabic. Another interesting result of the study shows that, statistically, there is no difference concerning the 'proficiency level' of both groups in using LLS. In other words, both third and fourth year students of monolingual and bilingual speakers use most of the strategies quite similarly, and there is no distinctive difference in favor of any of the levels in terms of using more strategies. And the final result of the study reveals that the participants of both groups chose the same favorite sequence and arrangement of LLS when asked to state which of the six LLS categories describe their methods of learning English language better. There are, again, a number of studies that show different order 
of LLS when monolinguals and bilinguals are involved. All these results are gained because of different potential reasons stated in previous chapter. Educationally, the results of the study recommend that the language teachers should be aware that the mentioned strategies of Oxford are of great prominence to be taken into consideration while designing their program or curriculum of study. They need to produce appropriate and effective materials and to include a wide-ranging number of activities that make the students or learners, especially Kurdish monolingual and bilingual ESL learners, consult and utilize most of the mentioned strategies to enhance and improve their foreign or second language skills and abilities. As a final point, the findings of this study need to be reexamined through conducting more studies of this kind as the limited number of participants might not be enough to base your results on.

\section{REFERENCES}

Abdul-Razak, N. Z., Ismael, F., Abdul-Aziz, A., Babikkoi, M. A. (2012). Assessing the use of English language learning strategies among secondary school students in Malaysia. Procedia-Social and Behavioral Sciences, 66, 240 - 246.

Al-Haisoni, E. (2012). Language Learning Strategy Use of Saudi EFL Students in an Intensive English Learning Context. Asian Social Science, 13 (8), 115-127.

Al-Otaibi, G. (2004). Language Learning Strategy Use among Saudi EFL students and Its Relationship to Language Proficiency Level, Gender and Motivation. Unpublished $\mathrm{PhD}$ Dissertation, Indiana University of Pennsylvania.

Baker, W., and Boonkit, K. (2004). Learning Strategies in Reading and Writing: EAP Contexts. RELC Journal, 35(3), 299-328.

Bremner, S. (1997). Language learning strategies and language proficiency: Causes or outcomes? Perspectives, 9(2), 6-35.

Brown, D. H. (2007). Principles of language learning \& teaching (5th ed.). Pearson: Longman.

Chang, C. (2011). Language Learning Strategy Profile of University Foreign Language Majors in Taiwan. Electronic Journal of Foreign Language Teaching, 8(2), 201-215.

De Angelis, G. (2007). Third or Additional Language Acquisition. Toronto: Multilungual Matters LTD.

Ellis, G. and Sinclair, B. (1989). Learning to Learn English: A Course in Learner Training. Cambridge: Cambridge University Press.

Ellis, R. (1994). The study of second language acquisition (2nd ed.) London: Sage Publications.

Gerami, M. H., and Baighlou, S. M. G. (2011). Language learning strategies used by successful and unsuccessful Iranian EFL students. Procedia-Social and Behavioral Sciences, 29, $1567-1576$.

Griffiths C. (2013) The Strategy Factor in Successful Language Learning. UK Multilingual Matters.

Griggs, S. A. (1991). Learning Styles Counseling. ERIC Digest. Retrieved November $\quad 10 \quad$ from http://www.ericdigests.org/1992-4/styles.htm.

Hong-Nam, K.., and Leavell, A. (2006). Language Learning Strategy Use of ESL Students in an Intensive English Learning Context. System, 34(3), 399-415.

Liu, D. (2004). EFL Proficiency, Gender and Language Learning Strategy Use among a Group of Chinese Technological Institute English Majors. ARECLS E-Journal, 1, 1-15.
McLaughlin, B., and Nayak, N. (1989). Processing a new language: Does knowing other language make a difference? In W. H Dechert and M. Raupach (Eds.) Interlingual Process (pp. 516). Tubingen: Gunter Narr Verlag.

Nayak, N. Hansen, N., Krueger, N., and McLaughlin, B. (1990). Language learning strategies in monolingual and

multilingual adults. Language Learning, 40(2), 224

Niles, R. (2006). Science Buddies. Retrieved November 20 from Sciencebuddies.org:

http://www.sciencebuddies.org/science-fairprojects/projects_ideas/Soc_participants.shtml.

O'Malley, J. M., Chamot, A. U., Stewner-Manzanares, G., Kupper, L.J., and Russo, R.P. (1985). Learning strategies used by beginning and intermediate ESL students. Language Learning, 35(1), 21-46.

O’Malley, J. and Chamot, A. (1990). Learning Strategies in Second Language Acquisition. Cambridge: Cambridge University Press.

Oxford, R. (1990). Language Learning Strategies: What Every Teacher Should Know. New York: Newbury House.

Oxford, R. L. (2003). Language learning styles and strategies: An overview. Learning Styles \& Strategies/Oxford, GALA, 125

Qasimnejad, A., and Hemmati, F. (2014). Investigating the Language Learning Strategies used by Iranian Monolingual (Persian) and Bilingual (Persian_Turkish ) Speakers as EFL learners. Procedia-Social and Behavioral Sciences, 136, 26-30.

Richard, J., and Shmidt R. (2002). Longman Dictionary of Language Teaching \& Applied Linguistics ( $3^{\text {rd }}$ ed.). London: Pearson Education.

Rubin, J. (1975). What the "good language learner" can teach us. TESOL Quarterly, 9(1), 41-51.

Rubin, J. (1987). Learner strategies: Theoretical assumptions, research history and typology. In A. Wenden \& J. Rubin (Eds.), Learner strategies in language learning (pp. 15-30). Englewood, NJ: Prentice/Hall International.

Scrivener, J. (2011). Learning Teaching: The Essential Guide to English Language Teaching ( $3^{\text {rd }}$ ed.). London: Macmillan.

Skehan, P. (1989). Individual Differences in Second Language Learning. London: Edward Arnold.

Stern, H.H. (1992). Issues and Options in Language Teaching. Oxford: OUP.

Wharton, G. (2000). Language learning strategy use of bilingual foreign language learners in Singapore. Language Learning, 50(2), 203-244.

Weaver, S., and Cohen, A. (1997). Strategies-Based Instruction: A Teacher-Training Manual. Minneapolis, MN: Center for Advanced Research on Language Acquisition, University of Minnesota.

Wenden, A. L. (1986). Helping language learners think about learning. ELT Journal, 40 (1), 3-12.

White, C. (2008). Language Learning Strategies in Independent Language Learning: An Overview. In T. W. Lewis \& M. S. Hurd (Eds.), Language Learning Strategies in Independent Settings (pp. 3-24). Clevedon, England: Multilingual Matters.

Zare, P. (2010). An Investigation into Language Learning Strategy Use and Gender among Iranian Undergraduate Language Learners. World Applied Sciences Journal 11 (10), 12381247. 


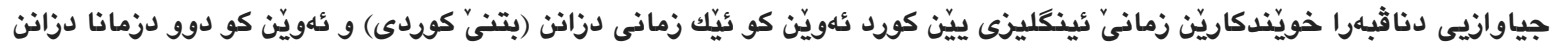

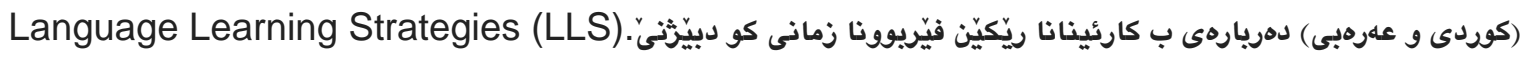

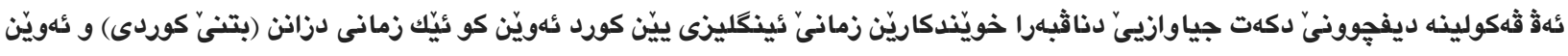

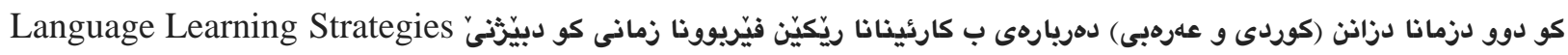

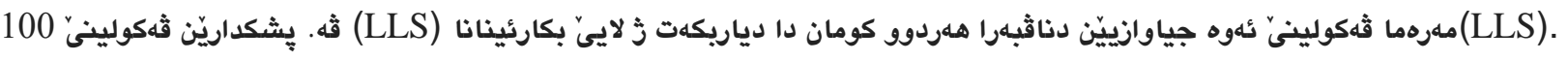

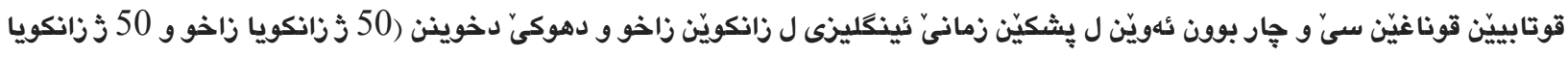

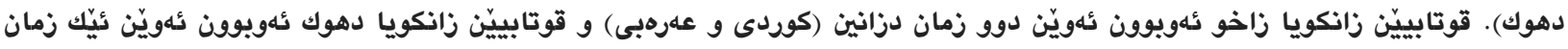

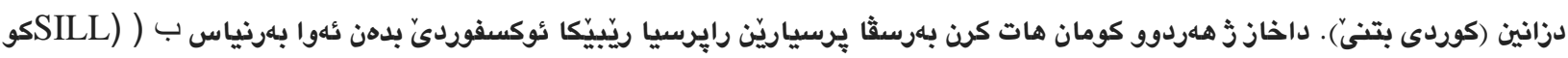

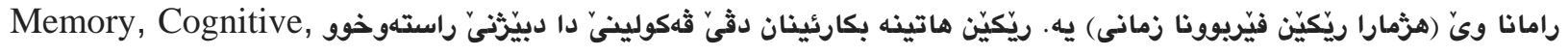

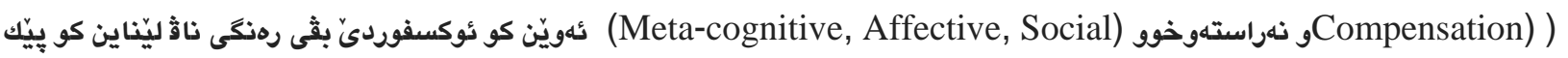

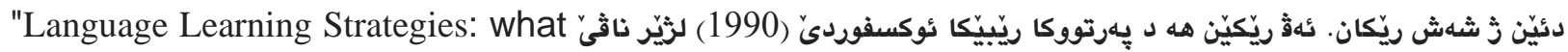

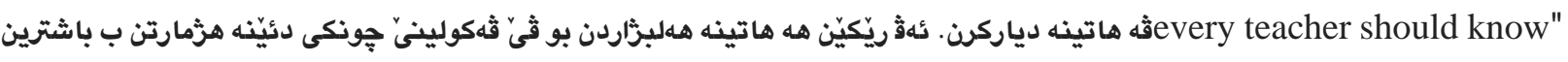

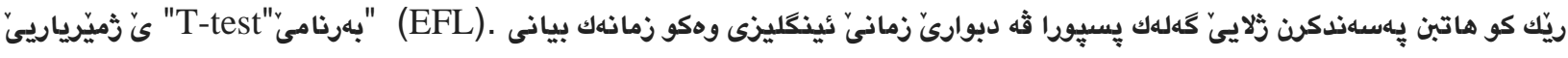

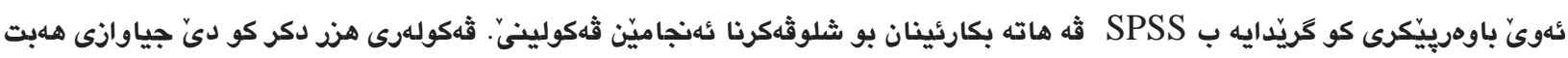

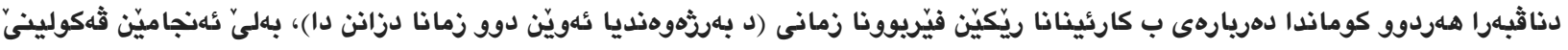

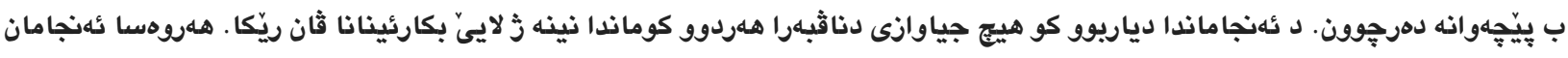

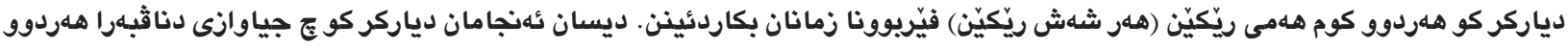

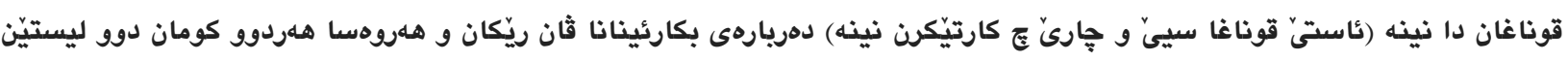

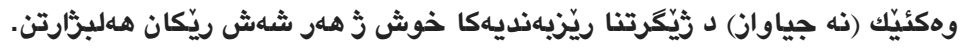

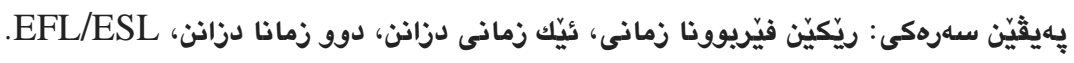

الفرق بين متعلمي اللغة الإنكليزية من ذوي لغة واحدة (اللغة الكردية) وذوي لغتين (اللغة الكردية والعربية) من الكرد فيما يتعلق باستخدام استراتيجيات تعليم اللغة (LLS)

الخلاصة:

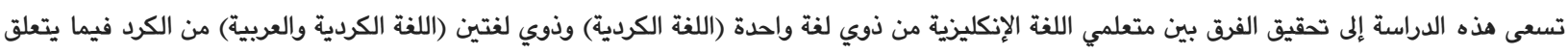

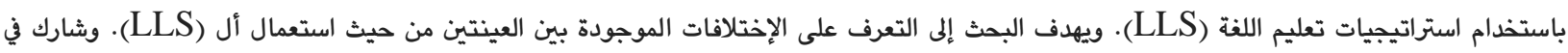

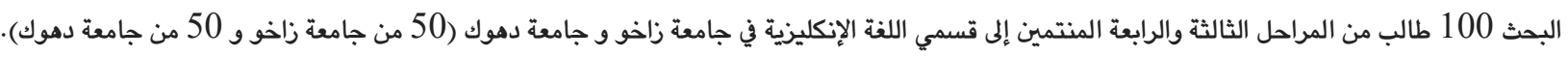

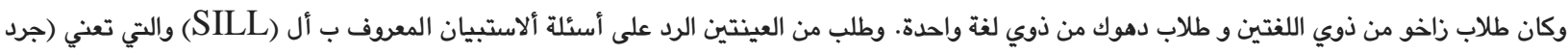

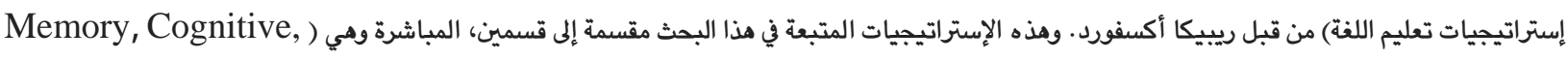

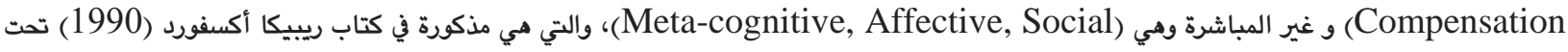
مسمى "Language Learning Strategies: what every teacher should know و ". وتم اختيار هذه الإستراتيجيات لهذا البحث لأنها

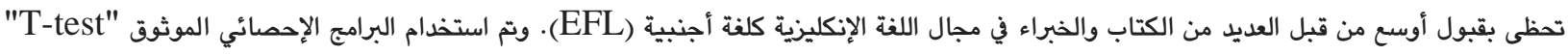

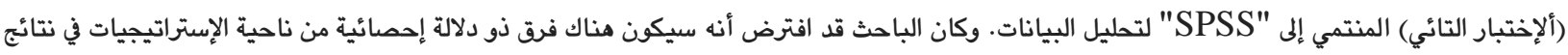

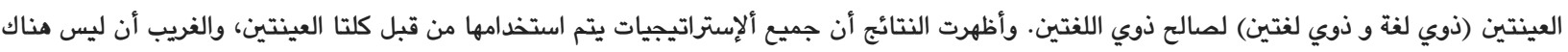

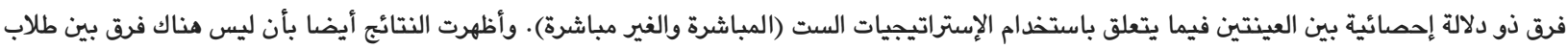

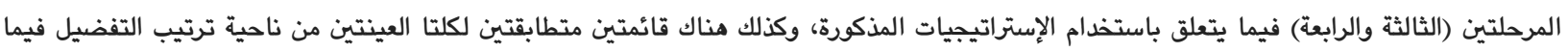

يتعلق باستعمال استراتيجيات تعليم اللغة (SLL).

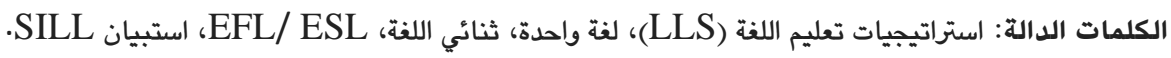


Appendix1：Strategy Inventory for Language Learning (SILL) Questionnaire

\section{Strategy Inventory for Language Learning (SILL)}

This form of the strategy inventory for language learning (SILL) is for students of a second language (SL). Please read each statement and fill in the bubble of the response $(1,2,3,4$, or 5) that tells HOW TRUE THE STATEMENT IS.

1. Never or almost never true of me

2. Usually not true of me

3. Somewhat true of me

4. Usually true of me

5. Always or almost always true of me

Answer in terms of how well the statement describes you. Do not answer how you think you should be, or what other people do. There are no right or wrong answers to these statements.

\section{Part A}

1. I think of relationships between what I already know and new things I leam in the SL.

2. I use new SL words in a sentence so I can remember them.

3. I connect the sound of a new SL word and an image or picture of the word to help me remember the word.

4. I remember a new SL word by making a mental picture of a situation in which the word might be used.

5. I use rhymes to remember new SL words.

6. I use flashcards to remember new SL words.

7. I physically act out new SL words.

8. I review SL lessons often.

9. I remember new SL words or phrases by remembering their location on the page, on the board, or on a street sign.

$$
\begin{aligned}
& { }_{1}{ }^{\curvearrowright}{ }^{\curvearrowright} 3^{\curvearrowright} 4^{\curvearrowright} 5 \\
& { }_{1}{ }^{\curvearrowright} 2^{\curvearrowright} 3^{\curvearrowright} 4^{\curvearrowright} 5 \\
& { }_{1}{ }^{\wedge} 2^{\curvearrowright}{ }_{3}{ }_{4}{ }^{\circ} 5 \\
& { }_{1}{ }^{\curvearrowright} 2^{\curvearrowright} 3^{\curvearrowright} 4^{\curvearrowright} 5 \\
& { }_{1}{ }^{\curvearrowright} 2^{\curvearrowright} 3^{\curvearrowright} 4^{\curvearrowright} 5 \\
& { }_{1}{ }^{\circ}{ }_{2}{ }_{3}{ }^{\circ} 4^{\curvearrowright} 5 \\
& { }_{1}{ }^{\curvearrowright}{ }^{\curvearrowright} 3^{\curvearrowright} 4^{\curvearrowright} 5 \\
& { }_{1}{ }^{\curvearrowright}{ }^{\curvearrowright} 3^{\curvearrowright} 4{ }_{4} 5 \\
& { }_{1}{ }^{\circ}{ }_{2}{ }_{3}{ }^{\circ} 4{ }^{\circ} 5
\end{aligned}
$$

\section{Part B}

10. I say or write new SL words several times.

11. I try to talk like native SL speakers.

12. I practice the sounds of SL.

13. I use the SL words I know in different ways.

14. I start conversations in the SL.

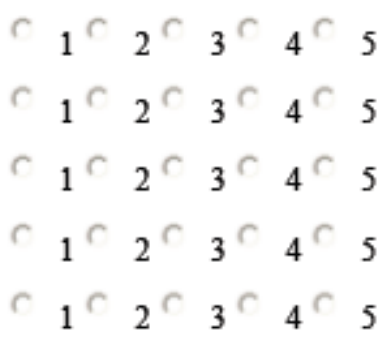


15. I watch SL language TV shows spoken in SL or go to movies spoken in SL.

16. I read for pleasure in the SL.

17. I write notes, messages, letters, or reports in the SL.

$$
\begin{aligned}
& 1^{\curvearrowright} 2^{\curvearrowright} 3^{\curvearrowright} 4{ }^{\curvearrowright} 5 \\
& { }_{1}{ }^{\curvearrowright} 2^{\curvearrowright} 3^{\curvearrowright} 4^{\curvearrowright} 5 \\
& { }_{1}{ }^{\curvearrowright}{ }_{2}{ }^{\circ} 3^{\curvearrowright} 4^{\curvearrowright} 5
\end{aligned}
$$

18. I first skim an SL passage (read over the passage quickly) then go back and read carefully.

19. I look for words in my own language that are similar to new words in the SL.

20. I try to find patterns in the SL.

21. I find the meaning of an SL word by dividing it into parts that I understand

22. I try not to translate word for word.

23. I make summaries of information that $I$ hear or read in the SL.

\section{Part C}

24. To understand unfamiliar SL words, I make guesses.

25. When I can't think of a word during a conversation in the SL, I use gestures.

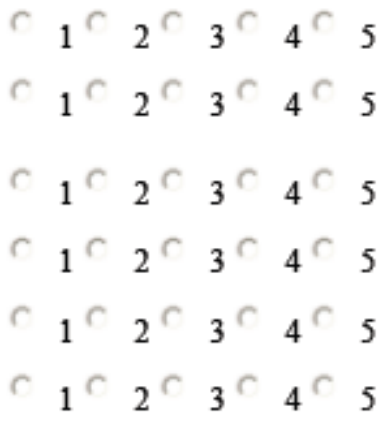

26. I make up new words if I do not know the right ones in the SL.

27. I read SL without looking up every new word.

28. I try to guess what the other person will say next in the SL.

29. If I can't think of an SL word, I use a word or phrase that means the same thing.

\section{Part D}

30. I try to find as many ways as I can to use my SL.

31. Inotice my SL mistakes and use that information to help me do better.

32. I pay attention when someone is speaking SL.

33. I try to find out how to be a better learner of SL.

34. I plan my schedule so I will have enough time to study SL.

35. I look for people I can talk to in SL. 
36. I look for opportunities to read as much as possible in SL.

$$
\begin{aligned}
& { }^{\curvearrowright}{ }_{1}^{\curvearrowright} 2^{\curvearrowright} 3^{\curvearrowright} 4^{\curvearrowright} 5
\end{aligned}
$$

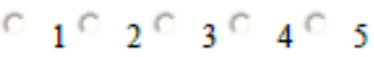

$$
\begin{aligned}
& { }_{1}{ }^{\curvearrowright}{ }^{\curvearrowright} 3^{\curvearrowright} 4^{\curvearrowright} 5
\end{aligned}
$$

I have clear goals for improving my SL skills.

38. I think about my progress in learning SL.

\section{Part E}

39. I try to relax whenever I feel afraid of using SL.

40. I encourage myself to speak SL even when I am afraid of making a mistake.

\begin{tabular}{|c|c|c|c|c|}
\hline & $1^{r}$ & $2^{r}$ & $3^{r}$ & $4^{r}$ \\
\hline & $1^{\curlyvee}$ & $2^{r}$ & $3^{r}$ & $4^{r}$ \\
\hline & $1^{\curlyvee}$ & $2^{\Upsilon}$ & $3^{r}$ & $4^{r}$ \\
\hline & ${ }_{1} \curvearrowright$ & $2^{r}$ & $3^{r}$ & $4^{r}$ \\
\hline & $1^{r}$ & $2^{r}$ & $3^{r}$ & $4^{r}$ \\
\hline & $1^{r}$ & $2^{\curlyvee}$ & $3^{r}$ & $4^{r}$ \\
\hline
\end{tabular}

\section{Part F}

45. If I do not understand something in SL, I ask the other person to slow down or say it again.

46. I ask SL speakers to correct me when I talk.

47. I practice SL with other students.

48. I ask for help from SL speakers.

49. I ask questions in SL.

50. I try to learn about the culture of SL speakers.

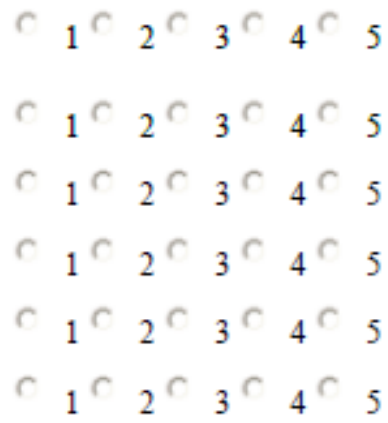

